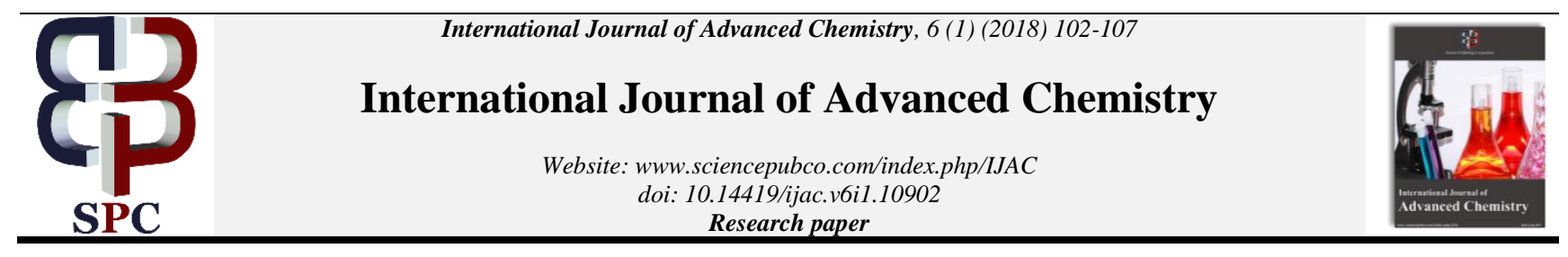

\title{
Kinetics and mechanism of the reduction of n-(2-hydroxyethyl)ethylenediaminetriacetatoiron(III) complex by thioglycol in bicarbonate buffer medium
}

\author{
I.U. Nkole ${ }^{1 *}$, C.R. Osunkwo ${ }^{1}$, A.D. Onu ${ }^{2}$, O.S. Idris ${ }^{1}$ \\ ${ }^{1}$ Department of Chemistry, Ahmadu Bello University, Zaria, Nigeria \\ ${ }^{2}$ Department of Chemistry, Federal University of Education, Zaria, Nigeria \\ *Corresponding author E-mail:nkoleikechukwu@gmail.com
}

\begin{abstract}
The kinetics and mechanism of reduction of $\mathrm{N}$-(2-hydroxyethyl) ethylenediaminetriacetatoiron (III) complex (hereafter [Fe(III)HEDTAOH $\left.\mathrm{H}_{2}\right]$ ) by thioglycol (hereafter RSH) has been studied spectrophotometrically in a bicarbonate buffer medium. The study was carried out under pseudo-first order conditions of an excess of thioglycol concentration at $28 \pm 1{ }^{\circ} \mathrm{C}, \mathrm{I}=0.44 \mathrm{~mol} \mathrm{dm}{ }^{-3}$ $\left(\mathrm{KNO}_{3}\right)$ and $\lambda \max =490 \mathrm{~nm}$. The reaction is first order in [Fe(III)HEDTAOH $]$ and half order in [RSH] and a stoichiometric mole ratio of [Fe(III)HEDTAOH 2 ]: RSH is 2:1. Reaction rates increased with increase in ionic strength (I) and dielectric constant (D) of the reaction medium of the reaction. The reaction displayed positive primary salt effect, which suggests the composition of activated complex are likely charged reactants ions. Test for possibility of an intermediate complex formation shows negative as MichaelisMenten plot was linear with very negligible intercept. Based on the findings, outer-sphere mechanism is proposed for the reaction. The experimental rate law obtained is; $-\frac{\mathrm{d}\left[\mathrm{Fe}(\mathrm{III}) \mathrm{HEDTAOH}_{2}\right]}{\mathrm{dt}}=\mathrm{k}_{2}\left[\mathrm{Fe}(\mathrm{III}) \mathrm{HEDTAOH}_{2}\right][\mathrm{RSH}]^{1 / 2}$
\end{abstract}

Keywords: Kinetics; N-(2-Hydroxyethyl)ethylenediaminetriacetatoiron(III) Complex; Mechanism; Thioglycol; Reduction

\section{Introduction}

The kinetic studies of electron transfer reactions of thioglycol have recorded much interest since it has been employed to act as a biological antioxidant by scavenging hydroxyl radicals (Aitken, et al., 2008). Thioglycol undergoes electron transfer reaction by deprotonation and loss of one electron in mostly alkaline media. It has wide application in preventing protein oxidation (Verdugn et al., 1985), denaturing of ribonucleases (Nelson et al., 2015) and reducing proteins (Stevens et al., 9183). The reactions of this substrate have been of interest. The review of its oxidations with different substrates (Chakraborty and Banerjee, 2014; Chakraborty et al., 2012; Shanmugaprabha et al., 2016; Chakraborty et al., 2013; Goswami et al., 2003) and its dimerization to form disulfide in biological systems have been studied (Messmore et al., 2000). Equally, kinetics study on the reduction of $\mathrm{Fe}(\mathrm{III})$ aminocarboxylates complexes(Wang et al., 2008; Balahura and Johnson, 1987; Buettner et al., 1983; Xiao-juan et al., 2011; Francis et al., 1985; Bull et al., 1983; Suchecki et al., 2014; Mshelia et al., 2014; Dellert-Ritter and Eldik, 1992) by various reducing substrates have been scantly recorded.

The basis of this study is centered on the electron transfer reaction of this oxidant, and the quest to provide additional kinetic data that will shed more light on the pathway of the reaction in terms of Taube's inorganic electron transfer reaction mechanistic classification.

\section{Experimental details}

The [Fe(III)HEDTAOH 2 ] complex was prepared according to the method of Xiao-juan et al., 2011 and was characterized using UV/Visible. The UV/Visible spectrum of [Fe(III)HEDTAOH ${ }_{2}$ ] was scanned between ranges of $300-700 \mathrm{~nm}$ and gave $\lambda_{\max }$ of 360 and $490 \mathrm{~nm}$.

$\mathrm{N}$-(2-Hydroxyethyl)ethylenediaminetriacetatoiron(III) complex was prepared by adding standard solution of ferric nitrate (SigmaAldrich) and HEDTA (Sigma-Aldrich) in a ratio such that EDTA was in slight excess to ensure complete complexation. $\mathrm{KNO}_{3}$ (BDH) was used to maintain ionic strength. The complex stock solution had a concentration of about $0.05 \mathrm{~mol} \mathrm{dm}^{-3}$. Prior to use, the solution's $\mathrm{pH}$ is adjusted to 7.5 with bicarbonate buffer solution.

\subsection{Stoichiometric studies}

The stoichiometry was determined by spectrophotometric titration using the mole ratio approach (Onu et al., 2016) under the reaction condition $\left[\mathrm{Fe}(\mathrm{III}) \mathrm{HEDTAOH}_{2}\right]=4.5 \times 10^{-3} \mathrm{~mol} \mathrm{dm}^{-3}, \mathrm{I}=0.1 \mathrm{~mol}$ $\mathrm{dm}^{-3}, \mathrm{pH}=7.5,[\mathrm{RSH}]=(0.9-11.7) \times 10^{-3} \mathrm{~mol} \mathrm{dm}^{-3}$.

\subsection{Kinetic measurements}

The progress of the reaction rate was monitored under pseudo first order condition by observing change in absorbance of the reduct- 
ant on Sherwood Colorimeter 254 at a $\lambda_{\max }$ of $490 \mathrm{~nm}$. The $\mathrm{pH}$, temperature and ionic strength were kept constant. The plot of log $\left(\mathrm{A}_{\mathrm{t}}-\mathrm{A}_{\infty}\right)$ versus time using the first order rate equation

$\log \left(A_{t}-A_{\infty}\right)=\frac{k t}{2.303}+\log \left(A_{t}-A_{\infty}\right)$

Was linear up to $90 \%$ of the reaction (Fig. 1). The pseudo-first order rate constant, kobs, of the reaction was determined from the slope of the plot and are presented in Table 1 . The log of $\mathrm{k}_{\mathrm{obs}}$ versus $\log [\mathrm{RSH}]$ was plotted. Keeping all other reactions conditions constant as shown on (Tables 1 and 2), the influence of $\mathrm{pH}(6-$ $10)$ and dielectric constant $(75.5-80.1)$ and ionic strength $(0.2-$ 1.0) $\mathrm{mol} \mathrm{dm}^{-3}$ using $\mathrm{KNO}_{3}$ was investigated for the reaction.

\subsection{The effect of added ion on the reaction rate}

The effect of added oxalate ion on the reaction was investigated at $\left[\mathrm{C}_{2} \mathrm{O}_{4}{ }^{2-}\right]=(1.0-21.0) \times 10^{-3} \mathrm{~mol} \mathrm{dm}^{-3}$ while all other reactants concentration were kept constant at $\mathrm{I}=0.44 \mathrm{~mol} \mathrm{dm}{ }^{-3}\left(\mathrm{KNO}_{3}\right)$.

\subsection{Free radical test}

The investigation of participation of free radical was done by adding $3.00 \mathrm{~cm}^{3}$ of standard solution of acrylamide to a partially reduced reaction mixture containing various concentrations of oxidant and reductant and followed by addition of a large excess of methanol. The same treatment was applied to solution of reductant and oxidant separately.

\subsection{Temperature dependence}

The effect of temperature on the reaction rate was investigated to ascertain the thermodynamic parameters of the reaction medium by using Eyring's plot of In $\left(\mathrm{k}_{2} / \mathrm{T}\right)$ versus $1 / \mathrm{T}$, where in enthalpy of activation $\Delta \mathrm{H}^{\ddagger}$ is obtained from the slope, entropy of activation $\Delta \mathrm{S}^{*}$ is from the intercept. The Eyring's equation is given as;

$\operatorname{In}\left(k_{2} / T\right)=\operatorname{In}\left(K_{b} / h\right)+\Delta S^{\ddagger} / R-\Delta H^{\ddagger} / R T$

\subsection{Product analysis}

The UV/Visible spectrum of the reaction product was scanned between wavelength ranges of $400-600 \mathrm{~nm}$ gave a $\lambda_{\max }$ of 520 $\mathrm{nm}$, which is characteristic of the $\mathrm{Fe}(\mathrm{II})$ product (Iyun, 2004; Idris et al., 2008), and the appearance of a red colour on addition of 1 , 10- phenanthroline reveals the presence of $\mathrm{Fe}(\mathrm{II})$ product (Ellis et al.,1975). Investigation of the formation of sulfenic acid (RSOH) at the completion of the reaction was done by reducing the product with sodium ascorbate and sodium arsenite to thiol, which is confirmed by red colour formation when sodium nitroprusside or ammonium hydroxide is added to the test mixture (Saurin et al., 2004; Kettenhofen and Wood, 2010; Eaton, 2006; Gupta and Carroll, 2014).

\section{Results and discussion}

\subsection{Stoichiometry}

The spetrophotometric titrations showed oxidant - reductant ratio of 2:1 represented by the stoichiometric equation;

$$
\begin{aligned}
& 2\left[\mathrm{Fe}(\mathrm{III}) \mathrm{HEDTAOH}_{2}\right]+\mathrm{RSH} \rightarrow 2\left[\mathrm{Fe}(\mathrm{II}) \mathrm{HEDTA}^{-}+\mathrm{RSOH}+\right. \\
& 2 \mathrm{H}^{+}+\mathrm{H}_{2} \mathrm{O}
\end{aligned}
$$

\subsection{Kinetic study}

The linearity of the pseudo-first order plots of $\log \left(A_{t}-A_{\infty}\right)$ versus time (Fig. 1) with $90 \%$ extent of reaction indicates that the reaction is first order with respect to [Fe(III)HEDTAOH $\mathrm{H}_{2}$. The half order dependence with respect to $[\mathrm{RSH}]$ obtained is rationalized by the plot of $\log \mathrm{k}_{\text {obs }}$ versus $\log [\mathrm{RSH}]$ having a slope of 0.55 (Fig. 2). The half order reaction as obtained with respect to the concentration of reductant is known to proceeds either by monomer-polymer equilibria with the monomeric species being the reactive form (Wilkins, 2002; Fawzy et al., 2017), or molecular dissociation (Berry et al., 1980; Onu et al., 2016). The redox reactions of first order dependence on [Fe(III)HEDTAOH ${ }_{2}$ ] have been reported (Buettner et al., 1983; Francis et al., 1985). The half order dependence on $[\mathrm{RSH}]$ as obtained for the $\left[\mathrm{Fe}(\mathrm{III}) \mathrm{HEDTA}\left(\mathrm{OH}_{2}\right)\right] / \mathrm{RSH}$ reaction is uncommon, and it indicates the termination of the chance for the growth of a polymer chain that could has resulted to the formation of disulfide, but end up forming sulfenic acid, RSOH (Misra and Dubey, 1981).

Table 1:Pseudo-First Order and Second Order Rate Constants for the Reaction of $\left[\mathrm{Fe}(\mathrm{III}) \mathrm{HEDTAOH}_{2}\right]$ and RSH at [Fe(III)HEDTAOH $\left.\mathrm{H}_{2}\right]=4.5 \mathrm{x}$ $10^{-3} \mathrm{~mol} \mathrm{dm}^{-3}, \mathrm{I}=0.44 \mathrm{~mol} \mathrm{dm}^{-3}\left(\mathrm{KNO}_{3}\right), \mathrm{pH}=7.5, \mathrm{~T}=28 \pm 1^{\circ} \mathrm{C}$ and $\lambda_{\max }$ $=490 \mathrm{~nm}$

\begin{tabular}{lllll}
$10^{2}[\mathrm{RSH}], \mathrm{mol} \mathrm{dm}^{-3} \mathrm{pH}$ & $\mathrm{I}, \mathrm{mol} \mathrm{dm}$ & $10^{3} \mathrm{k}_{\mathrm{obs}}, \mathrm{s}^{-1}$ & $10^{2} \mathrm{k}_{3 / 2}, \mathrm{dm}^{3 / 2} \mathrm{~mol}^{-1 / 2} \mathrm{~s}^{-1}$ \\
\hline 1.0 & 7.5 & 0.44 & 1.25 & 1.00 \\
2.0 & 7.5 & 0.44 & 1.97 & 1.00 \\
3.0 & 7.5 & 0.44 & 2.53 & 1.07 \\
4.0 & 7.5 & 0.44 & 2.92 & 1.09 \\
5.0 & 7.5 & 0.44 & 3.26 & 1.12 \\
6.0 & 7.5 & 0.44 & 3.52 & 1.11 \\
7.0 & 7.5 & 0.44 & 3.76 & 1.12 \\
8.0 & 7.5 & 0.44 & 3.99 & 1.13 \\
7.0 & 6.0 & 0.44 & 12.21 & 4.61 \\
7.0 & 6.5 & 0.44 & 3.87 & 1.46 \\
7.0 & 7.0 & 0.44 & 4.03 & 1.52 \\
7.0 & 7.5 & 0.44 & 3.57 & 1.35 \\
7.0 & 8.0 & 0.44 & 5.53 & 2.09 \\
7.0 & 8.5 & 0.44 & 8.28 & 3.13 \\
7.0 & 9.0 & 0.44 & 13.73 & 5.19 \\
7.0 & 9.5 & 0.44 & 10.48 & 3.96 \\
7.0 & 7.5 & 0.30 & 2.67 & 1.01 \\
7.0 & 7.5 & 0.40 & 3.64 & 1.38 \\
7.0 & 7.5 & 0.50 & 4.87 & 1.84 \\
7.0 & 7.5 & 0.60 & 6.48 & 2.45 \\
7.0 & 7.5 & 0.70 & 7.95 & 3.00 \\
7.0 & 7.5 & 0.80 & 8.04 & 3.04 \\
7.0 & 7.5 & 0.90 & 8.35 & 3.14 \\
7.0 & 7.5 & 1.00 & 8.36 & 3.15 \\
\hline & & & &
\end{tabular}

Time (sec)

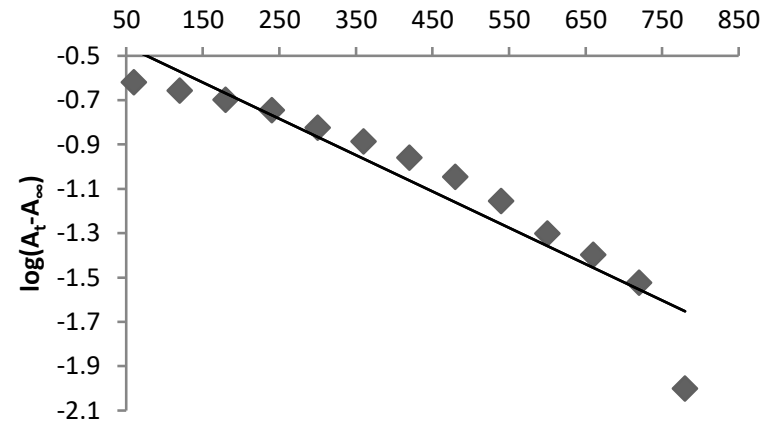

Fig. 1: Typical Pseudo-First Order Plot For The Reaction Of [Fe(III) $\mathrm{HEDTAOH}_{2}$ and RSH at [Fe(III)HEDTAOH $\left.{ }_{2}\right]=4.5 \times 10^{-3} \mathrm{~mol} \mathrm{dm}^{-3}$, $[\mathrm{RSH}]=7.0 \times 10^{-2} \mathrm{~mol} \mathrm{dm}^{-3}, \mathrm{I}=0.44 \mathrm{~mol} \mathrm{dm}^{-3}\left(\mathrm{KNO}_{3}\right), \mathrm{pH}=7.5, \mathrm{~T}=28$ $\pm 1^{\circ} \mathrm{C}$, and $\lambda_{\max }=490 \mathrm{~nm}$

Stoichiometry 2:1 obtained in this reaction has been documented with reaction involving thiol (Shi et al., 1996). 


\section{$\log [\mathrm{RSH}]$}

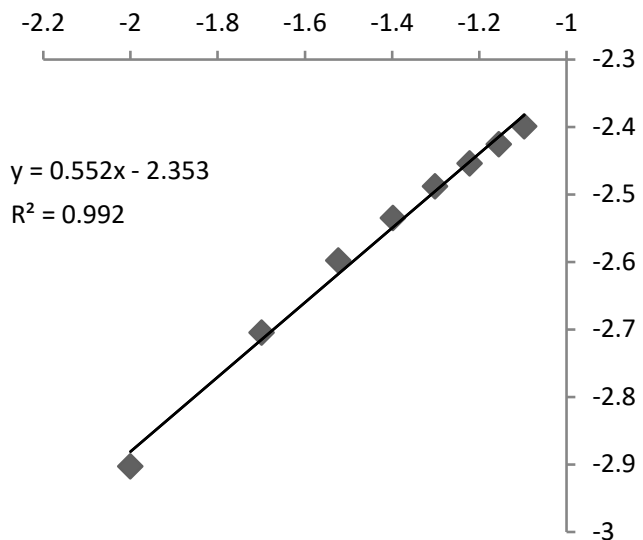

Fig. 2: Plot of $\log \mathrm{k}_{\mathrm{obs}}$ versus $\log [\mathrm{RSH}]$ for the Reaction of $\left[\mathrm{Fe}(\mathrm{III}) \mathrm{HEDTAOH}_{2}\right]$ and RSH at $\left[\mathrm{Fe}(\mathrm{III}) \mathrm{HEDTAOH}_{2}\right]=4.5 \times 10^{-3} \mathrm{~mol}^{-3}$ $\mathrm{dm}^{-3},[\mathrm{RSH}]=(1.0-8.0) \times 10^{-2} \mathrm{~mol} \mathrm{dm}{ }^{-3}, \mathrm{I}=0.44 \mathrm{~mol} \mathrm{dm}^{-3}\left(\mathrm{KNO}_{3}\right), \mathrm{pH}=$ $7.5, \mathrm{~T}=28 \pm 1^{\circ} \mathrm{C}$, and $\lambda_{\max }=490 \mathrm{~nm}$
VI

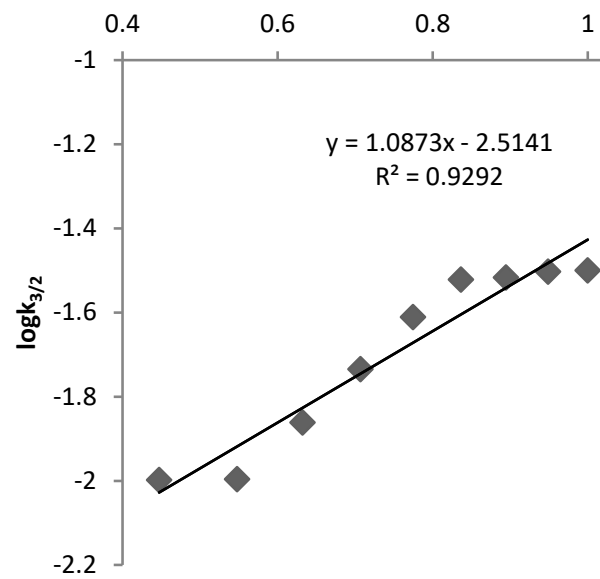

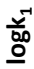

Fig. 3: Plot $\log \mathrm{k}_{3 / 2}$ versus $\sqrt{\mathrm{I}}$ for the Reaction of [Fe(III)HEDTAOH $\mathrm{H}_{2}$ and $\mathrm{RSH}$ at $\left[\mathrm{Fe}(\mathrm{III}) \mathrm{HEDTAOH}_{2}\right]=4.5 \times 10^{-3} \mathrm{~mol} \mathrm{dm}^{-3}$, $[\mathrm{RSH}]=7.0 \times 10^{-2} \mathrm{~mol}$ $\mathrm{dm}^{-3}, \mathrm{I}=(0.2-1.0) \mathrm{mol} \mathrm{dm}{ }^{-3}, \mathrm{pH}=7.5, \mathrm{~T}=28 \pm 1^{\circ} \mathrm{C}$, and $\lambda_{\max }=490 \mathrm{~nm}$

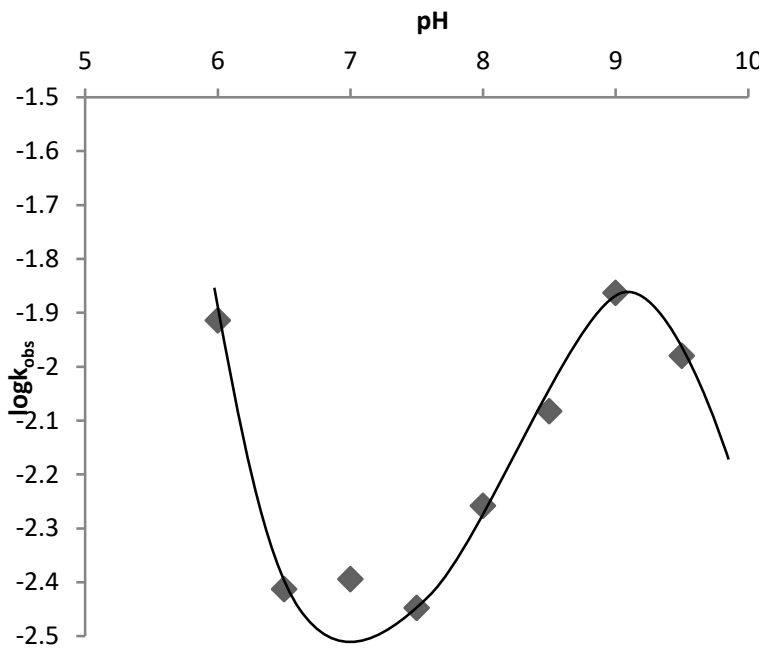

Fig. 4: Plot of $\log \mathrm{k}_{\mathrm{obs}}$ versus $\mathrm{pH}$ for the Reaction of [Fe(III)HEDTAOH $\mathrm{H}_{2}$ ] and $\mathrm{RSH}$ at $\left[\mathrm{Fe}(\mathrm{III}) \mathrm{HEDTAOH}_{2}\right]=4.5 \times 10^{-3} \mathrm{~mol} \mathrm{dm}^{-3}$, $[\mathrm{RSH}]=7.0 \times 10^{-2}$ $\mathrm{mol} \mathrm{dm}-3, \mathrm{I}=0.44 \mathrm{~mol} \mathrm{dm}^{-3}\left(\mathrm{KNO}_{3}\right), \mathrm{T}=28 \pm 1^{\circ} \mathrm{C}$, and $\lambda_{\max }=490 \mathrm{~nm}$
3.2.1. Effect of changes in ionic strength and dielectric constant of reaction medium on reaction rates

The influence of ionic strength of the reaction medium by varying it from $0.3-1.0 \mathrm{~mol} \mathrm{dm}^{-3}\left(\mathrm{KNO}_{3}\right)$ is positive on the rate constants of the reaction by increasing it (Table 1). This suggests the presence of charged ions at the activated complex. This is supported by the effect of changes in the dielectric constant, D, from 75.5 80.1 on the rates of the reaction. It was observed that the reaction rate increases with increased medium polarity.

Table 2: Effect of Changes in the Dielectric Constant of Reaction Medium on the Rate Constants for the Reduction of [Fe(III)HEDTAOH $\mathrm{H}_{2}$ By $\mathrm{RSH}$ at $\left[\mathrm{Fe}(\mathrm{III}) \mathrm{HEDTAOH}_{2}\right]=4.5 \times 10-3 \mathrm{~mol} \mathrm{dm}^{-3}$, $[\mathrm{RSH}]=7.0 \times 10^{-2} \mathrm{~mol} \mathrm{dm}^{-}$ ${ }^{3}, \mathrm{I}=0.44 \mathrm{~mol} \mathrm{dm}^{-3}\left(\mathrm{KNO}_{3}\right), \mathrm{pH}=7.5, \mathrm{~T}=28 \pm 1^{\circ} \mathrm{C}$, and $\lambda_{\max }=490 \mathrm{~nm}$

\begin{tabular}{lll}
$\mathrm{D}$ & $10^{3} \mathrm{k}_{\text {obs }}, \mathrm{s}^{-1}$ & $10^{2} \mathrm{k}_{3 / 2}, \mathrm{dm}^{3 / 2} \mathrm{~mol}^{-1 / 2} \mathrm{~s}^{-1}$ \\
\hline 80.1 & 3.76 & 1.42 \\
79.5 & 3.64 & 1.38 \\
78.9 & 3.12 & 1.18 \\
78.4 & 2.98 & 1.13 \\
77.8 & 2.74 & 1.04 \\
77.2 & 2.05 & 0.77 \\
76.7 & 1.96 & 0.74 \\
76.1 & 1.36 & 0.51 \\
75.5 & 1.26 & 0.48 \\
\hline
\end{tabular}

\subsubsection{Effect of $\mathrm{pH}$ on reaction rates}

The investigation of $\mathrm{pH}$-dependent on the reaction rate reveals that changes in $\mathrm{pH}(6.0-9.5)$ affected the reaction rate (Table 1), wherein there is a marked increase in the reaction rate at $\mathrm{pH}=6.0$, the dominance of the $\left[\mathrm{Fe}(\mathrm{III}) \mathrm{HEDTAOH}_{2}\right]$ is expected, while at $\mathrm{pH}=9.0$, deprotonation can take place resulting to $[\mathrm{Fe}(\mathrm{III}) \mathrm{HEDTA}(\mathrm{OH})]^{-}$ion. Also, the rate-pH profile (Fig. 4) shows that both the ionized thiol (thiolate ion, $\mathrm{RS}^{-}$) and thiyl specie (RS) of the substrate are active species involved in the electron transfer, and non- participation of the hydroxyl specie of the complex in the redox process (Sami et al., 2009; Ghosh et al., 2013; Gangopadhyay et al., 1994).

\subsubsection{Effect of added oxalate ion on reaction rate}

There was positive Bronsted salt effect which can be accounted for by the interactions of the like charges in reaction.

\subsubsection{Detection of free radicals}

The polymerization test to ascertain the presence of active participation of free radicals in the reaction was positive as gelatinous precipitate was formed on the addition of acrylamide to partially reduced reaction mixture in excess methanol.

\subsubsection{Effect of temperature on reaction rates}

In temperature study with activation parameters $\left(\Delta \mathrm{S}^{\ddagger}=-242.6\right.$ $\left.\mathrm{Jmol}^{-1} \mathrm{~K}^{-1}, \Delta \mathrm{H}^{\ddagger}=8.15 \mathrm{kJmol}^{-1} \& \Delta \mathrm{G}^{\ddagger}=81.17 \mathrm{kJmol}^{-1}\right)$, the large negative value of entropy of activation clearly indicates the result of a large mutual ordering of solvated water molecules at equilibrium and electron transfer step. The values of enthalpy of activation and Gibbs free energy indicate the energy of formation associated with the precursor complex ([Fe(III)HEDTA $\left.(\mathrm{OH})]^{-}\right)$and the energy of intermolecular electron transfer step (Weaver and Yee, 1980). 
$1 / \mathrm{T}$

0.00290 .002950 .0030 .003050 .00310 .003150 .00320 .00325

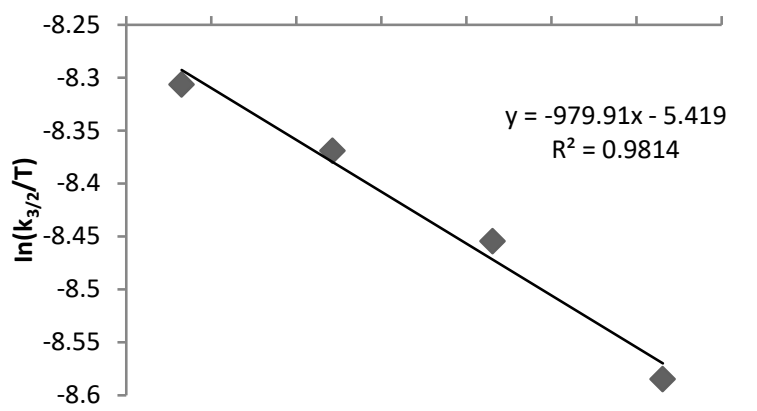

Fig. 5: Plot of In $\left(\mathrm{k}_{3 / 2} / \mathrm{T}\right)$ Versus $1 / \mathrm{T}$ for the Reaction of [Fe(III)EDTAOH $\left.{ }_{2}\right]$ and RSH at $\left[\mathrm{Fe}(\mathrm{III}) \mathrm{EDTAOH}_{2}\right]=4.5 \mathrm{X} \mathrm{10}^{-3} \mathrm{~mol} \mathrm{dm}^{-3}$, $[\mathrm{RSH}]=7.0 \times 10^{-2} \mathrm{~mol} \mathrm{dm}^{-3}, \mathrm{I}=0.44 \mathrm{~mol} \mathrm{dm}^{-3}\left(\mathrm{KNO}_{3}\right), \mathrm{pH}=7.5$ and $\lambda_{\max }$ $=490 \mathrm{~nm}$

\subsubsection{Michaelis-Menten plot}

Michaelis-Menten plot of $1 / \mathrm{k}_{\text {obs }}$ versus $1 /[\mathrm{RSH}]^{1 / 2}$ was linear without any glaring intercept (Fig. 6). This confirms the absence of stable intermediate, but probably the formation of ion-pair (Osunlaji et al., 2012). The above findings support the suggestion that outer-sphere mechanism is operating in the reduction of the $\mathrm{Fe}(\mathrm{III})$ ion.

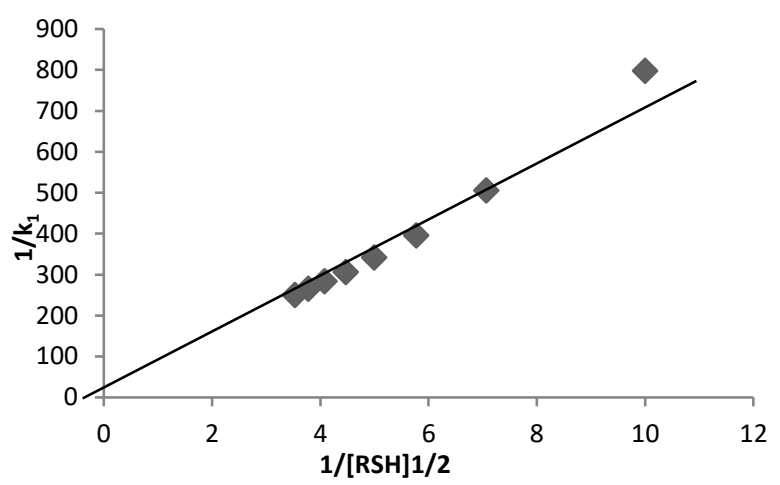

Fig. 6: Michaelis-Menten Plot of $1 / \mathrm{k}_{\text {obs }}$ versus $1 /[\mathrm{RSH}]^{1 / 2}$ for the Reduction of [Fe(III)HEDTAOH $\mathrm{H}_{2}$ by $\mathrm{RSH}$

The empirical data is accounted for by the following mechanistic scheme which is in favor of the outer-sphere reaction.

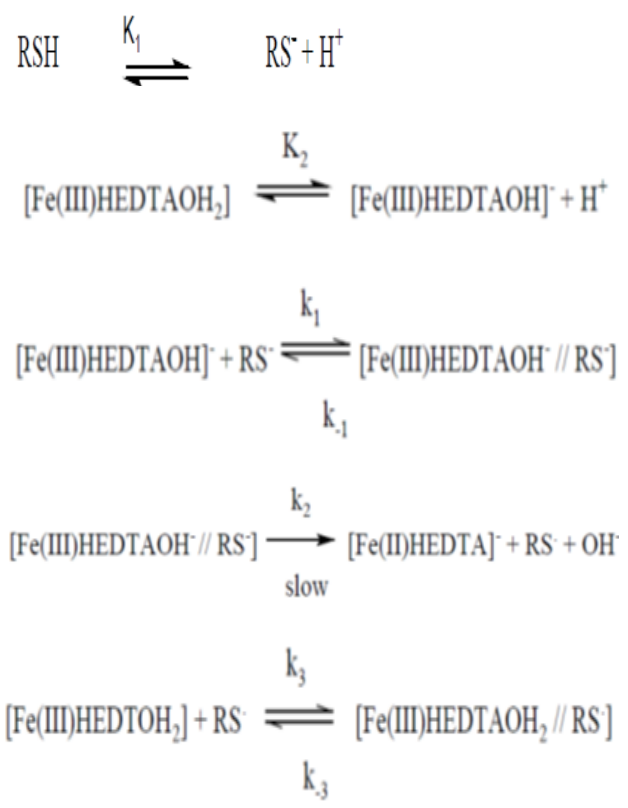

$\left[\mathrm{Fe}(\mathrm{III}) \mathrm{HEDTAOH} \mathrm{H}_{2} / / \mathrm{RS}\right] \underset{\text { slow }}{\stackrel{\mathrm{k}_{4}}{\longrightarrow}}[\mathrm{Fe}(\mathrm{II}) \mathrm{HEDTA}]^{\circ}+\mathrm{RSOH}+\mathrm{H}^{+}$

$\mathrm{OH}^{+}+\mathrm{H}^{+} \underset{\text { fast }}{\stackrel{\mathrm{k}_{5}}{\longrightarrow}} \mathrm{H}_{2} \mathrm{O}$

Therefore,

Rate $=\mathrm{k}_{2}\left[\mathrm{Fe}(\mathrm{III}) \mathrm{HEDTAOH}^{-} / / \mathrm{RS}^{-}\right]+\mathrm{k}_{4}\left[\mathrm{Fe}(\mathrm{III}) \mathrm{HEDTAOH}_{2} / /\right.$ $\mathrm{RS}$ ]

From equation 6;

$$
\left[\mathrm{Fe}(\mathrm{III}) \mathrm{HEDTAOH}^{-} / / \mathrm{RS}^{-}\right]=\mathrm{k}_{-1}\left[\mathrm{Fe}(\mathrm{III}) \mathrm{HEDTAOH}^{-}\right]\left[\mathrm{RS}^{-}\right]
$$

From equation 5;

$$
\left[\mathrm{Fe}(\mathrm{III}) \mathrm{HEDTAOH}^{-}\right]=\frac{\mathrm{K}_{2}\left[\mathrm{Fe}(\mathrm{III}) \mathrm{HEDTAOH}_{2}\right]}{\left[\mathrm{H}^{+}\right]}
$$

Substituting equation 13 into equation 12

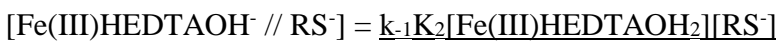

Substituting equation 14 into equation 11

Rate $=\underline{\mathrm{k}}_{2} \underline{\mathrm{k}}_{-1} \underline{\mathrm{K}}_{2}\left[\mathrm{Fe}(\mathrm{III}) \mathrm{HEDTAOH}_{2}\right]\left[\mathrm{RS}^{-}\right]+\mathrm{k}_{4}\left[\mathrm{Fe}(\mathrm{III}) \mathrm{HEDTAOH}_{2} / / \mathrm{RS}\right]$ $\left[\mathrm{H}^{+}\right]$

Also, from equation 8;

$\left[\mathrm{Fe}(\mathrm{III}) \mathrm{HEDTAOH}_{2} / / \mathrm{RS} \cdot\right]=\mathrm{k}_{-3}\left[\mathrm{Fe}(\mathrm{III}) \mathrm{HEDTAOH}_{2}\right][\mathrm{RS} \cdot]$

Substituting equation 16 into equation 15

Rate $=\underline{\mathrm{k}}_{2} \underline{\mathrm{k}_{1}} \underline{\underline{\mathrm{K}}} \underline{\underline{2}}\left[\mathrm{Fe}(\mathrm{III}) \mathrm{HEDTAOH}_{2}\right]\left[\mathrm{RS}^{-}\right]+\mathrm{k}_{4} \mathrm{k}_{3}\left[\mathrm{Fe}(\mathrm{III}) \mathrm{HEDTAOH}_{2}\right][\mathrm{RS}]$ $\left[\mathrm{H}^{+}\right]$

If $[\mathrm{RSH}]=\left[\mathrm{RS}^{-}\right]=\left[\mathrm{RS}^{-}\right]^{2} ;\left[\mathrm{RS}^{-}\right]=\mathrm{K}_{1}{ }^{1 / 2}[\mathrm{RSH}]^{1 / 2}$

Hence,

Rate $=\underline{\mathrm{k}}_{2} \underline{\mathrm{k}}_{-} \underline{\mathrm{K}}_{2} \underline{\mathrm{K}}_{1}^{1 / 2}[\mathrm{Q}][\mathrm{RSH}]^{1 / 2}+\mathrm{k}_{4} \mathrm{k}_{-3} \mathrm{~K}_{1}^{1 / 2}[\mathrm{Q}][\mathrm{RSH}]^{1 / 2}$ $\left[\mathrm{H}^{+}\right]$

Where $[\mathrm{Q}]=\left[\mathrm{Fe}(\mathrm{III}) \mathrm{HEDTAOH}_{2}\right]$

$$
\text { Rate }=\left(\mathrm{k}_{2} \mathrm{k}_{-1} \mathrm{~K}_{2} \mathrm{~K}_{1}{ }^{1 / 2}\left[\mathrm{H}^{+}\right]^{-1}+\mathrm{k}_{4} \mathrm{k}_{-3} \mathrm{~K}_{1}^{1 / 2}\right)\left[\mathrm{Fe}(\mathrm{III}) \mathrm{HEDTAOH}_{2}\right]
$$
$[\mathrm{RSH}]^{1 / 2} \quad(19)$

Rate $=\mathrm{k}\left[\mathrm{Fe}(\mathrm{III}) \mathrm{HEDTAOH}_{2}\right][\mathrm{RSH}]^{1 / 2}$

Where $\mathrm{k}=\mathrm{k}_{2} \mathrm{k}_{-1} \mathrm{~K}_{2} \mathrm{~K}_{1}{ }^{1 / 2}\left[\mathrm{H}^{+}\right]^{-1}+\mathrm{k}_{4} \mathrm{k}_{-3} \mathrm{~K}_{1}^{1 / 2}$

However, equation 20 conforms to experimental rate law.

\section{Conclusion}

The kinetics and mechanism of reduction of $\mathrm{N}-(2-$ hydroxyethyl)ethylenediaminetriacetatoiron(III) complex by thioglycol was studied in bicarbonate buffer medium. A mole ratio of 2:1 (Complex: Oxidant) was obtained. The analysis of other kinetic data obtained under the pseudo-first order condition gave an overall order of one and half; first order with respect to the concentration of the oxidant and half order with respect to the concentration of the reductant. Rationalizing the pieces of evidence obtained in the study favors the outer-sphere mechanism and a plau- 
sible mechanistic pathway which explains the kinetic data obtained is proposed.

\section{Acknowledgments}

The authors are grateful to Department of Chemistry, Ahmadu Bello University Zaria for her assistant in this research.

\section{References}

[1] Aitken, C.E., Marshall, R.A. and Puglisi, J.D. (2008). An Oxygen Scavenging System for Improvement of Dye Stability in Singlemolecule Fluorescence Experiments.Biophysical Journal, 94(5): 1826 - 1835.https://doi.org/10.1529/biophysj.107.117689

[2] Verduyn, C., Van Kleef, R., Frank, J., Schreuder, H., Van Dijken, J.P. and Scheffers, W. A. (1985). Properties of the NAD(P)Hdependent Xylose Reductase from the Xylose-Fermenting Yeast Pichia stipitis. The Biochemical Journal. 226(3): 669 77..https://doi.org/10.1042/bj2260669.

[3] Nelson, D.R., Lehninger, A.L. and Cox, M. (2005). Lehninger Principles of Biochemistry. New York: W.H. Freeman, 148. ISBN 0-7167-4339-6.

[4] Stevens, R., Stevens, L. and Price, N.C. (1983). The Stabilities of Various Thiol Compounds used in Protein Purifications. Biochemical Education. 11(2): 70.https://doi.org/10.1016/03074412(83)90048-1.

[5] Chakrabarty, S. and Banerjee, R. (2014). Kinetics and Mechanism of Oxidation of 2-Mercaptoethanol by the Heteropolyoxovanadate $\left[\mathrm{MnV}_{13} \mathrm{O}_{38}\right]^{7-}$. International Journal of Chemical Kinetics, 47: $13-$ 18. https://doi.org/10.1002/kin.20887.

[6] Chakraborty, M., Mandal, P.C. and Mukhopadhyay, S. (2012). Kinetic Studies on Oxidation of L-Cysteine and 2-mercaptoethanol by a TrinuclearMn(II) Species in Aqueous Acid media. Inorganic ChimicaActa 398: 82.https://doi.org/10.1016/j.poly.2012.07.011.

[7] Shanmugaprabha, T., Selvakumar, K., Rajasekaram, K. and Sami, P. (2016). A Kinetic Study of the Oxidations of 2-mercaptoethanol and 2-mercaptoethylamine by Heteropoly 11-tungsto-1vanadophosphate in Aqueous Acid Medium. Transition Metal Chemistry, 41: 177 - 185.https://doi.org/10.1007/s11243-015-9998$\mathrm{y}$.

[8] Chakraborty, M., Mandal, P.C. and Mukhopadhyay, S. (2013). Kinetic Studies on Oxidation of L-cysteine and 2-mercaptoethanol by a TrinuclearMn(IV) Species in Aqueous Acidic Media. InorganicaChimicaActa, $\quad 37$ https://doi.org/10.1016/j.ica.2012.12.015.

[9] Goswami, S., Shaikh, N., Panja, A. and Banerjee, P. (2003). A Comparative Kinetics Study for the Oxidation of 2mercaptoethanol by di- $\mu$-oxo-bis $(1,4,7,10$-tetraazacyclododecane)dimanganese(III, IV) and di- $\mu$-oxo-bis $(1,4,8,11$ tetraazacyclotetradecane)-dimanganese(III, IV) Complexes: Influence of Copper(II). Indian Association of Cultivation of Science, 129 - 137. https://doi.org/10.1002/kin.10182.

[10] Messmore, J.M., Holmgren, S.K., Grilley, J.E. and Raines, R.T. (2000). Sulfur Shuffle: Modulating Enzymatic Activity by Thiol Disulfide Interchange. Bioconjugate Chemistry, 11(3): 408 413.https://doi.org/10.1021/bc990142m.

[11] Wang, Z., Liu, C., Wang, X., Matthew, J.M., Zachara, J.M., Rosso, K.M., Dupuis, M., Fredrickson, J.K., Heald, S. and Shi, L. (2008). Kinetics of Reduction of Fe III) Complexes by Outer Membrane Cytochromes MtrC and OmcA of Shewanellaoneidensis MR-1. Ap plied \& Environmental Microbiology, 74(21): 6746 - 6755. https://doi.org/10.1128/AEM.01454-08.

[12] Balahura, R.J. and Johnson, M.D. (1987). Outer-Sphere Dithionite Reductions of Metal Complexes. Inorganic Chemistry, 26: $3860-$ 3863..https://doi.org/10.1021/ic00270a010.

[13] Buettner, G.R., Doherty, T.P. and Patterson, R.K. (1983). The Kinetics of the Reaction of Superoxide Radical with Fe (II1) Complexes of EDTA, DETAPAC, and HEDTA. Federation of European Biochemical Societies, 158(1): 143 146.https://doi.org/10.1016/0014-5793(83)80695-4

[14] Xiao-juan, Y., Lin, Y., Li, D., Xiang-Li, L. and Wei-Kang, Y. (2011). Kinetics of the [Fe (III) EDTA] ${ }^{-}$Reduction by Sulfite under the Catalysis of Activated Carbon. Journal of American Chemical Society. 25: 4248 - 4255. https://doi.org/10.1021/ef2006063.

[15] Francis, K.C., Cummins, D. and Oakes, J. (1985). Kinetics and Structural Investigations of $\left[\mathrm{Fe}^{\mathrm{III}}(\right.$ edta $\left.)\right]-[\mathrm{edta}=$ Ethylenediaminetet- raacetate(4-)] Catalyzed Decomposition of Hydrogen Peroxide. Journal of Chemical Society, Dalton Transtion. 4:493 501.https://doi.org/10.1039/DT9850000493.

[16] Bull, C., McClune, G.J. and Fee, J.A. (1983). The Mechanism of Fe-EDTA Catalyzed Superoxide Dismutation. Journal of American Chemical Society, 105(16): 5290 5300.https://doi.org/10.1021/ja00354a019.

[17] Suchecki, T.T., Mathews, B., Augustyniak, A.W. and Kumazawa, H. (2014). Applied Kinetics Aspects of Ferric EDTA Complex Reduction with Metal Powder. Industrial \& Engineering Chemistry Research, 53: 14234 - 14240...https://doi.org/10.1021/ie502100h.

[18] Mshelia, M.S., Iyun, J.F., Uzairu, A. and Idris S.O. (2014). Kinetics and Mechanisms of the Oxidation of $[\text { FeEDTA }]^{2-}$ by Aqueous Iodine. International Journal of Engineering \& Science Inventory, 3 : $2319-6726$.

[19] Dellert-Ritter, M. and Eldik, R. (1992). Kinetics and Mechanism of the Redox Behavior of the Ethylenediamintetraacetatoferrate(III) Sulfite System in Aqueous Solution. Journal of Chemical Society, Dalton Transition, 1045 1049.https://doi.org/10.1039/DT9920001045.

[20] Onu, A.D. Iyun, J.F. Idris, S.O. (2016). Oxidation of Ethylenediamine-tetraactatocobaltate(II) Complex by Hydrogen Peroxide in Aqueous Acidic Medium: A Kinetic Study. Journal of Nigerian Chemical Society, 41(2): $81-86$.

[21] Iyun, J.F. (2004). The Oxidation of some Tris-(diimine) iron (II) and Tris-(substituted diimine) iron (II) Complexes by Aqueous Acidic Bromine Solution. An Assessment of the Marcus Model for Non - Complimentary Reactions. ChemClass Journal. 59 - 63.

[22] Idris, S.O., Iyun, J.F. and Agbaji, E.B. (2008). Kinetics and Mechanism of Oxidation of Thiosulfate Ion by Tetrakis(2,2-Bipyridine)$\mu$-oxodiiron(III) Ion in Aqueous Acidic Medium. ChemClass Journal, $103-108$

[23] Ellis, K.J., Lappin, G. and McAuley, A. (1975). Metal-Ion Oxidation in Solution: Rate- determining Dimerizations in Redox Reactions of Iron (III) with some $\alpha$-mercaptocarboxylic Acids. Journal of American Chemical Society. Dalton Transition, 1931 - 1934

[24] Saurin, A.T., Neubert, H., Brennan, J.P. and Eaton, P. (2004). Widespread Sulfenic Acid Formation in Tissues in Response to Hydrogen Peroxide. Proceedings of the National Academy of Sciences, USA, 101: 17982 17987.https://doi.org/10.1073/pnas.0404762101.

[25] Kettenhofen, N.J. and Wood, M.J. (2010). Formation, Reactivity, and Detection of Protein Sulfenic Acids. Chemical Research Toxicology, 23:1633 - 1646. https://doi.org/10.1021/tx100237w.

[26] Eaton, P. (2006). Protein Thiol Oxidation in Health and Disease: Techniques for Measuring Disulfides and Related Modifications in Complex Protein Mixtures. Free Radical Biology Medical, 40: 1889 - 1899. Gupta, V. and Carroll, K.S. (2014). Sulfenic Acid Chemistry, Detection and Cellular Lifetime. BiochimicaETBiophys$\begin{array}{lllll}\text { icaActa, } & 1840: & 847 & - & 875 .\end{array}$ https://doi.org/10.1016/j.freeradbiomed.2005.12.037.

[27] Gupta, V. and Carroll, K.S. (2014). Sulfenic Acid Chemistry, Detection and Cellular Lifetime. BiochimicaETBiophysica Ac-ta, 1840: 847 - 875.https://doi.org/10.1016/j.bbagen.2013.05.040.

[28] Shi, T., Berglund, J. and Elding, L.I. (1996). Kinetics and Mechanism for Reduction of Trans-dichlorotetracyanoplatinate(IV) by Thioglycolic Acid, L-Cysteine, DL-Penicillamine, and Glutathione in Aqueous Solution. Inorganic Chemistry, 35(12): 3498 3503.https://doi.org/10.1021/ic951598s

[29] Wilkins, R.G. (2002). Kinetics and Mechanism of Reactions of Transition Metal Complexes. Second Edition, Wiley-VCH Verlag GmbH \& Co., 65 - 75.ISBNs: 3-527-28253-X (Hardback); 3-52760082-5 (Electronic).

[30] Fawzy, A., Gluesmi, N., Althagafi, I.I. and Asghar, B.H. (2017). A Study of Kinetics and Mechanism of Chromic Acid Oxidation of Isosorbide, a Chiral Biomass-derived Substrate in Aqueous Perchlorate Solution. Transition Metal Chemistry, 42: 229 - 236

[31] Berry, R.S., Rice, S.A. and Ross, J. (1980). Physical Chemistry. John Wiley \& Son Inc.New York, 1179 - 1185.

[32] Misra, G.S. and Dubey, G.P. (1981). Aqueous Polymerization of Acrylamide Initiated by Ce (IV) - Thioglycolic Acid Redox System. Journal of Macromolecular Science Chemistry, A16 (3): $601-$ 613. https://doi.org/10.1080/00222338108056808.

[33] Sami, P., Venkateshwari, K., Mariselvi, N., Sarathi, A. and Rajasekaram, K. (2009). Studies on Electron Transfer Reaction of Heteropoly 11-tungstophosphosphovanadate (V) by L-cysteine and Thioglycolic Acid in Aqueous Acid Medium. Transition Metal Chemistry, 34: 733 - 737.https://doi.org/10.1007/s11243-009-92553. 
[34] Ghosh, G.K., Misra, K., Baskim, M., Linert, W. and Moi, S.C. (2013). Kinetics and Mechanism of the Interaction of di- $\mu$-hydroxobis(1,10-phenanthroline)dipalladium(II) Perchlorate with Thioglycolic Acid and Glutathione in Aqueous Solution. Journal of Solution Chemistry, 42: 526 - 543.https://doi.org/10.1007/s10953-0139973-1.

[35] Gangopahyay, S., Ali, M., Dutta, A. and Banerjee, P. (1994). Oxidation of Thioglycolic Acid and Glutathione by (trans-cyclohexane1, 2-diamine-N, N, N1, N1-tetraacetato) manganese (III) in Aqueous Media. Journal of American Chemical Society.Dalton Transition, 3: 841 - 845.https://doi.org/10.1039/DT9940000841.

[36] Weaver, M.J. and Yee, E.L. (1980). Activation Parameters for Homogenous Outer-sphere Electron Transfer Reactions. Comparison between Self -Exchange, and Cross-Reactions using Marcus Theory. Inorganic Chemistry, 19 1936.https://doi.org/10.1021/ic50209a023.

[37] Osunlaja, A.A., Idris, S.O. and Iyun, J.F. (2012). Mechanism of the Reduction of Methylene Blue by Thiourea in Aqueous Acid Medium. International Journal of ChemTecch Research, 4(2): $609-$ 617. 